\title{
Overcoming Corporal Punishment of Children: an Evaluation Toward Indonesian Penal Policy Nowdays
}

\author{
Rusmilawati Windari ${ }^{1 *}$, Supanto $^{2}$,Widodo Tresno Novianto ${ }^{2}$ \\ ${ }^{1} \mathrm{Ph} . \mathrm{D}$ Student at Faculty of law, University of Sebelas Maret and Lecture at University of Trunojoyo \\ Madura, Madura, Indonesia \\ ${ }^{2}$ Faculty of Law, University of Sebelas Maret, Surakarta, Indonesia
}

\begin{abstract}
Currently, corporal punishment is no longer accepted as an effective measure in disciplining children. Under Article 19, 28, and 37 of the CRC, it has been regarded as breach of child's right. Since 2006, the United Nations has evoked all countries to conduct legal reform pertaining prohibition of this act in all settings. Until today, Indonesia has been reviewed as a country where corporal punishment of children remains lawful. Nonetheless, Indonesian Government has rejected the review and insisted that the current penal policy is sufficient to protect children from that deed. In fact, the implementation of current penal policy toward corporal punishment unfortunately came up with problems of law enforcement. For instances, law enforcement against Aop Saopuddin and Dharmawati's cases that apparently has surpassed the limits of criminal law itself, and brought about injustice for teachers. This paper provides a qualitative analysis of Indonesian penal policy relating to physical violence against children. It discusses a single issue, namely: has penal policy of Indonesia nowdays been appropriate to overcome corporal punishment of children?. This paper urges legislators to re-evaluate as well as to improve the quality of penal policy in respect to overcome corporal punishment of children fairly.
\end{abstract}

\section{INTRODUCTION}

Full prohibition against corporal punishment of children nowadays seems to be an urgent need and constitutes as a manifestation of children protection in modern age. This can be said due to corporal punishment isknown as a quick and effective means in child care and education that remains to be frequently used by most of parents, teachers or other guardianin order to gain child's obedience. Although it was practically popular in the early $19^{\text {th }}$ century, however in some recent societies, it still widely gains social acceptance. As stated by Avi I. Mint in her article entitled Pain and Education, parents and teachers easily inflict pain

\footnotetext{
*Corresponding Author:wiendari@gmail.com / rusmila_09@yahoo.com
} 
through administering corporal punishment to their children (pupils), from very mild to severe level[1]. In a meanwhile, Jill Frankel and Ola Barnett also affirms that many cases of violence against children keep being unreported and hidden at the backdoor of homes or schools[2].

By definition, corporal punishment is pertinent to the infliction of physical pain or injury either with bare hands or tools such as ruler, wooden stick, rattan, belt, or even horsewhip, under good purposes of disciplining, controlling or correcting child's behaviour. It causes various degree of pain from mild to severe. Its form varies and unlimited, encompassing hitting, ear-twisting, pinching, beating, kicking, grabbing, shoving, ciggarette burning, standing in unpleasant position, swallowing improper food, and so forth.

Eliminating corporal punishment of children obviously is not an easy matter. Compared with other forms of violence that are very clear in their evil mind, corporal punishment stands in two paradoxal position. It can be either positive or negative means depending on view and belief of each society. People who view it positivelybase their argument on popular ancient english idiom "carrot and stick", which depicts the administration of reward and punishment in rearing and educating process in order to achieve child's obedient and well-behaviour[3]. In Indonesia, it is very well - recognized with a popular idiom "ada emas di ujung cemeti" (there is gold on the tip of the whip)". This idioms potrays that the punishment given to the child actually is for the favor of the future of the child himself. While, those who assume it as negative practices for children, argue that corporal punishment will lead to detrimental impacts to child 's growth and development.

Internationally, corporal punishment is regarded as a breach of child's rights under Article 19, 28, 37 of the UN Convention on the Rights of the Child (hereinafter referred to as the CRC 1989).Since 2006, the United Nations has evoked all countries to conduct legal reform pertaining prohibition of this act in all settings. According to global progress reported the Global Initiative to End Corporal Punishment of Children, there are 53 countries in 2018 that have achieved legal prohibition in all settings including in home, while the remaining 146 countries are considered to have no explicit prohibition in their respective legislations [4].

Until today, Indonesia unfortunately has been reviewed as one of 146 countries where corporal punishment of children remains lawful. The Human Rights Council asserted that Indonesia has no regulation containing explicit prohibition against corporal punishment of children. During early 2006 until 2012, Indonesian Government rejected the assessment as well as recommedation. At that moment, the government stated that the existing penal policy is sufficient to protect children from any forms of violence, including corporal punishment. However, the fact indicated differently. The implementation of penal policy toward corporal punishment cases came up with problems in law enforcement. For instances,in Aop Saopuddin and Dharmawati's cases.Law enforcement against those casesapparently had surpassed the limits of criminal law itself, and brought about injustice for most of teachers. Referring to some relevant cases occured, the Indonesian Government furthermore agreed to consider the recommendation of achieving full legal prohibition against corporal punishment of children. Precisely in the $27^{\text {th }}$ Universal Periodic Review (UPR) on Human Rights, which was taken place in Geneva in April-May 2017, the Indonesian government expressly stated its commitment to strive the prohibition against the use of corporal punishment of children in all settings[5].

The decision of Indonesian government to evaluate and also to conduct a profound analysis toward the relevant national legislation is also motivated by an escalation in amount of physical violence against children. According to Edi Suharto, the head of the Directorate of Child Social Welfare, Ministry of Social Affairs, it is known that the prevalence of physical violence against children in 2013 and 2014, as many as 3 million boys, and 1.5 million girls experienced physical violence[6]. For female child victims, around 66.4 percent 
was perpetrated by the mother, while 21,58 percent was conducted by the father. Whereas for male victims, $41.1 \%$ was perpetrated by fathers, and $40.35 \%$ was by mothers[6].

The above prevalence certainly does not describe the overall incidences of physical violence against children. However, violence against children remains a crime whose existence is like an iceberg phenomenon, in whichthe number of unrecorded cases actually are far more than the recorded ones. This paper provides a qualitative analysis of Indonesian penal policy governing physical violence against children. It discusses a single issue, namely: has penal policy of Indonesia nowdays been appropriate to deal with corporal punishment against children?. This paper urges both legislators and legal enforcers to reevaluate as well as to improve the quality of penal policy in respect to overcome corporal punishment of children fairly

\section{Pros and Cons of Corporal Punishment among Scholars}

In the scientific atmosphere, most of scholars agree that corporal punishment is a kind of violence. Johan V.Galtung (1990) categorizes it as violence with positive influence[7], while Black (1983) qualifies it as moralistic violence because it is geared to control one's behaviour[8].Yet,the debates among scholars as to whether it is permissible or not, or, criminally banned or not, are persistently lasting. The ancient philosophers such as Plato and Aristotle stay in parties supporting it as a correctional tool of children misbehaviour. John Locke, Immanuel Kant, John Dewey, Diana Baurimnd and David Benatar are quite different. They stand in the middle position. They confine that corporal punishment is acceptable by conditions of mild, infrequent, and administered by a good intention for children. While Quintilian, Kempe, Murray Strauss and Elizabeth Gershoff totally disagree and argue that violent ways in educating and nurturing children never worth good except causing injury to the child and breeding violent behaviours in the future.

Not much different from the pros and cons above, views of Indonesian experts on corporal punishment of children are also diverse. A child Protection expert, Seto Mulyadi considers thatcorporal punishment of children is the entrance of other severe violence against children, therefore, it shall be criminally banned. While, an Indonesian criminologist, Muhammad Mustofa and also a legal expert (as well as a judge of Supreme Court), Salman Luthan, consider that not all corporal punishment can be tackled by using criminal law, unless that act is administered unreasonably and has provenly caused serious injury to children[9].

\section{Facts of Physical Violence in Indonesia}

Today and most possibly in the future, violence against children is a kind of violence that may influentially threaten humanity. Concerning the meta-analytical research conducted by David Finkelhor et al, it is known that children are human beings who are most at risk of becoming victims of violence in any situation. It can be said that the intensity of children receiving violence is more than once everyday[10].

In Indonesia, the issue of child protection from all forms of violence lately has become a crucial problem that requires an appropriate as well as proportionate strategy of settlement. As affirmed by Yohana Susana Yembise, the Minister of Women Empowerment and Children Protection, the trend of violence against children in Indonesia has occured everywhere. The number of cases have been increasing from year to year, which require some comprehensive and in-depth studies of family, school and community to deal with the incidences. In addition to be a derivative of physical punishment, corporal punishment is also widely tolerated and used as a means to nurture and educate children. A lot of research 
show that the administration of punishment to children may bring about some negative eiher physically, psychologically, and even socially. In fact, not seldom some cases of physical punishment lead to child abuse.

Based on the global report released by Unicef in 2017, there are 73.7 percent of Indonesian children aged 1-14 years, experienced violent discipline, or psychological aggression or physical punishment at home, with an estimated number of 49,133,432 children[11].Other data are compiled by Alliance for the Elimination of Violence Against Children as written in the following table below:

Table 1

Data of Violence against children[12].

\begin{tabular}{|c|c|c|c|c|}
\hline No & Institution & Year & Numbe rof cases & Type of Violence \\
\hline 1 & KPAI & 2011-2016 & 22.109 & $\begin{array}{c}\text { The breach of child } \\
\text { rights, and } 50 \% \text { of } \\
\text { them are physical } \\
\text { violence }\end{array}$ \\
\hline 2 & FPK2PA & 2015-2017 & 101.59 & $\begin{array}{c}\text { Violence against } \\
\text { children and women }\end{array}$ \\
\hline 3 & $\begin{array}{l}\text { Komnas Anak } \\
\text { (Pusat Data dan } \\
\text { Informasi) }\end{array}$ & 2010-2014 & $\begin{array}{c}62 \% \text { violence } \\
\text { conducted by the closed } \\
\text { person }\end{array}$ & $\begin{array}{l}\text { Various, either } \\
\text { physical or other } \\
\text { forms of violence }\end{array}$ \\
\hline 4 & $\begin{array}{l}\text { UNICEF } \\
\text { Indonesia }\end{array}$ & 2015 & $\begin{array}{c}30 \% \text { of pupils } \\
\text { experience physical } \\
\text { violence at school }\end{array}$ & Physical violence \\
\hline 5 & $\begin{array}{c}\text { International } \\
\text { Center for } \\
\text { Research on } \\
\text { Women (ICRW) } \\
\text { dan } \\
\text { PlanInternasional }\end{array}$ & 2015 & $\begin{array}{c}84 \% \text { of pupils } \\
\text { experience physical } \\
\text { violence at school. } \\
\text { This number is } \\
\text { higher than trend } \\
\text { occured in Asia } \\
\text { namely as many as } \\
70 \%\end{array}$ & $\begin{array}{c}33 \% \text { the doers are } \\
\text { teachers }\end{array}$ \\
\hline
\end{tabular}

According to the series of data above, it appears that corporal punishment is achild protection issue that requires serious settlement This thing was stated by the government in the 2016-2020 National Child Protection Strategy, that corporal punishment of children is categorized as one of practices in child care and education that is harmful to the child's growth and development. Additionally, one-third of Indonesia's population are children aged 0-17 years, reaching around 82.8 million, or $32.9 \%$ of Indonesia's total population, which in 2017 already reached 262 million. Referring to that point, it means that there are 82.8 inhabitants of Indonesia who are at risk of becoming victims of violence and still need protection from all related parties from matters that violate their rights, including from corporal punishment.

\section{Court Rulings}

Two apprehensive cases of corporal punishment exemplified in this paper are court judgments which punish teachers causing minor pain or injury. The first case is the haircutting of student involving Aop Saopuddin, a teacher of student affairs in SDN Panjalin 
Kidul V, Majalengka - West Java. The case occured in March 2013 but moved forward with legal proceedings until October 2013. Initially, the case began from a disciplinary treatment performed by Aop Saopuddin based on a Principal's Decree of SDN Panjalin Kidul V No. 423.5/01-SD/2012. His conduct of slightly cut off hair of several long - haired male students eventually ended up to police report proposed by a parent of student named Tomy Himawan.

This case is exhaustive and leading up to judgment of Supreme Court (MA). According to Judgment No.257/Pid.B/2012/-PN.Mjl. and Judgment No. 226/PID/2013/- PT.BDG, both the District Court of Majalengka[13] and the appeals Court of Bandung[14] similarly declared him legally guilty for conducting an unpleasant act in a way of violence under Article 335 (1) of Penal Code. For his deed, Aop Saopuddin then was sentenced with 3 months imprisonment combined with 6 months probation. On the contrary, judges in the Supreme Court had different consideration. According to Judgement No. 1554/K/PID/2013, the judges decided to cancel the previous court rulings, to rule him innocent and to release him from all lawsuits under rationale of teacher protection. A judge of the Supreme Court, Salman Luthan stated that what Aop Saopuddin did to his students did not constitute a criminal act due to his act was already in line with the duty given to him and provided a good purpose of disciplining student behaviour[15].

The second case ensued to Dharmawati vs Ayu Ashari in 2017. Dharmawati, a teacher of islamic religion in one of Senior High School in Pare-Pare, South Celebes, was adjudicated guilty by the District Court of Pare-Pare. The lawsuit against her was conducting violence to Ayu Ashari, namely beating her student with Mukenah (female moslem prayer's outfit) because of making noise at Musholla and abandoning student's obligation of performing Dhuhur's Prayer together.

According to Judgement of the District Court of Pare-Pare No. 92/Pid.Sus/2017/PN Pre, dated on July 18,2017 , she was declared legally guilty committing a criminal act of violence against children under Article $76 \mathrm{C}$ juncto Article 80 of the Amendment of Child Protection Act No. 35 Year 2014. The court imposed her with 3 months imprisonment, combined with 7 months of probation. This case attracted public attention. Many people, notably the Indonesian Teachers Association (PGRI), assumed that the trial was unfair and deplored for what happened to Dharmawati. In their opinion, a teacher should not have been penalized just because of perfoming his/her duty in disciplining students, moreover, the impact caused by the teacher's act is insignificant to students.

\section{Penal Policy in Indonesia Nowdays}

The embodiment of holistic child protection is inseparable from the availability of legislation and policies that are responsive to child protection issues, one of which is the existence of criminal law legislation. Compared to other legal fields, criminal law has a distinctive character. Criminal law sets norms of orders and prohibited act, along with a series of criminal sanctions to sentence the offenders and control people's behavior. According to Jan Remmelinkcompliance with norms in criminal law is the imperative value of the criminal law itself[16].

AlthoughArticle 28 B paragraph (2) of National Constitution of 1945 and Article 58 paragraph (1) of Human Rights Act No.39 Year 1999 have acknowledged that protection from any sorts of violence is a child right, however, those legislations are not followed by the presence of other relevant regulations which specifically contain criminal norms regarding prohibition of corporal punishment. To date, the handling of corporal punishment issue only applies provisions on violence or abuse that are scattered in various legislations, namely: the Penal Code, the Amendment of Child Protection Act No 35 Year 2014, and the 
Elimination of Domestic Violence Act No. 23 Year 2004 (especially for domestic corporal punishment).

Of those legislations above, every case of corporal punishment in Indonesia which are brought to criminal proceedings may be qualified as violation of following acts:

(1) Violence, as stipulated in Article 335 paragraph (1) of Penal Code (the latest formulation in accordance with the decision of Contitutional Court No 1/PUU-XI/2013)

(2) Abuse, as stipulated in Article 351 - 353 of Penal Code;

(3) Deprivation of liberty, as stipulated in Article 333 paragraph (1) of Penal Code;

(4) Child Violence, as stipulated in Article 76 C juncto Article 80 of the Amendment of Child Protection Act No 35 Year 2014; and

(5) Physical Violence in domestic sphere as regulated in Article 5 juncto Article 44 of the Elimination of Domestic Violence Act No. 23 Year 2004.

When we further examine the formulation of substantive criminal norms enacted in all regulations above, we can find that norms of violence and abuse are formulated in different way. In relation to corporal punishment, Penal Code of Indonesia recognizes two models of formulation, namely: (1) only enacting juridical qualification without detailing the elements of conduct; and conversely (2) detailing the elements of conduct without mentioning the juridical qualification of conduct.

For provision of abuse as stipulated in Article 351 to 353, the Penal Code only formulates the qualification of abuse without further providing legal explanation or listing elements of which constitute the act of "abuse". Soesilo explains that the term of "abuse" as stipulated in Article 351 may be seen as any act which causes unpleasant feeling, pain, or injury, including health damage. While for provision of violence as stipulated in Article 335, the legal meaning of " violence" refers to Article 89 of Penal Code, which can be interpreted as unlawfully using power or force of which is not light, including any acts causing people fainted.

Tracing back the legal practice in the Netherlands in more than a century ago, the reach of acts which cause unpleasant feeling, pain and injury encompasses two views. Firstly, based on Arrest Hoge Raad (HR) issued at 25 June 1894, abuse means all kinds of act which deliberately cause pain or injury, including acts of parents or teacher administering corporal punishment against children. Another view is based on two Arrest Hoge Raad (HR) issued at 10 February 1902 and 20 April 1925 which state that an act of making pain or injury is not categorised as an abuse if it is conducted under good purposes and in proper and reasonable way. In other words, the provision abuse in Penal Code is excluded from reasonable corporal punishment in sphere of education and parenting. Many Indonesian scholars such as Sudarto, Tresna, Satochid Kartanegara, and also Soesilo agree with the second view. Sudarto even argues that reasonably beating children under purpose of educating or repairing misbehaved children is a substantive justification which may remove the defendant from sentencing[17].

Meanwhile, different from the Penal Code, Article 76 C juncto Article 80 Law No. 35 Year 2014 on the Amendment of Child Protection Act regulates that physical violence against children is firmly forbidden with more severe criminal sanction as a concequence. The Amendment of Child Protection Act provides a broad definition of violence as stipulated in Article 1 number 15a. It covers all acts of resulting in physical, psychological, sexual oppression or misery, and/or negligence, including a threat of doing some deeds, coercion or illegal deprivation of liberty. Whilst, Article 6 of the Elimination of Domestic Violence Act provides a more specific definition of physical violence encompassing every act that causes pain, sick, or seriously injury. 


\section{The Evaluation of Penal Policy}

In the context of Indonesian criminal law, the issue of corporal punishment of children is not specifically and explicitly regulated, but qualified as equivalent to abuse or other physical violence. Therefore, in law practice so far, any cases of corporal punishment submitted to the court are tried by applying several provisions of criminal legislation governing physical abuse or violence, including: Article 333, 335 paragraph (1) no. 1, 351-354 of the Penal Code, Article 76 C juncto Article 80 of Act Number 35 of 2014 concerning Amendments to Law Number 23 of 2002 concerning Child Protection, and Article 5juncto Article 44 of Act Number 23 of 2004 concerning Elimination of Domestic Violence.

At a glance, all regulations are adequately effective in handling corporal punishment cases. Unfortunately, they have some significant weaknesses which may become a stumbling block of law enforcement, including:

\subsection{A matter of ambiguity in juridical qualification}

As a kind of violence, both legislators, legal enforcers and also government representative in Indonesia consider that the criminal provisions governing violence and abuse are sufficient to deal with cases of corporal punishment against children. In this case, I partly agree with their view about legal position of corporal punishment. It can be denied that corporal punishment is a derivative form of physical violence, whose its constitutive elements are closely similar to abuse or physical violence as regulated in some existing criminal legislation. At glance, it is not wrong if positive legal rules apply to corporal punishment cases. This is very understandable insofar as long as the law does not bring about significant juridical consequences at the level of legal practice.

However, conceptually, the term of corporal punishment has a slight but significant differentiation with common violence or abuse, eventhough practically irrational and uncontrolled corporal punishment tends to risk at more severe abuse. As stated previously, corporal punishment against children can be defined as the imposition of punishment in form of pain or injury to child's bodywhich is motivated by good purpose of raising well-behavior of children. The existence of good purpose is a core element that differs corporal punishment from common physical violence or abuse.

According to Galtung, Donald Black, Nietzche and Jeremy Bentham, the term violence has a broad spectrum and is divided into several typologies. There is violence that has a positive connotation and there is a negative connotation. David Benatar Argues that eventhough corporal punishment is a form of violence, nevertheless, it is not always viewed amoral[18]. While Galtung in this case classifies itas a kind of violence with a positive impact [19]. Donald Black consider itas moralistic violencewhich means the use of violence is a tool of controlling moral or human behavior[20]. Lastly, Nietzche in his book entitled "On The Genealogy Moral" argues that the imposition of pain both physically and psychologically is justified on the basis of the need to educate children, discipline and avoid children from greater social sanctions [20].

If, in legal practice, corporal punishment is interpreted as a form of abuse or common violence as regulated in criminal legislation, a multi-interpreation among legal enforcers can not be eluded. It will open wide chance of easily qualify all forms of corporal punishment as criminal act of common violence or abuse. Hence, norms of criminal law are potentially over worked since the current legislation do not give an exception for mild corporal punishment with minor impacts. In other words, it sets aside consideration of severity, method, loss (harm) and motivation in assessing corporal punishment, so that in this case, principle of 
ultimum remedium seems to be unrealistic and fairness for some parties appears to be far from the reach.

In fact, legal practices in recent years have evidently shown problems in law enforcement as a result of the application of some current legislation toward cases of corporal punishment. Indeed, it has created injustice as well as worries for some involved parties. It can be seen in cases of Aop Saopuddin (2013) and Dharmawati (2017), in which both of teachers automatically became defendants and underwent criminal proceedings just because of administering a presumably mild corporal punishment. They were accused to had committed violence or abuse against their student eventhough what they did knowingly have a good purpose of disciplining their students. In addition to be exhausting for both of the teachers, the application of current criminal legislation toward corporal punishment cases has placed criminal law as a prime measure in dealing with social problem. Whereas criminal law essentially should be functioned as the last resort after all non-penal measures are put forward. As stated by Herbet L. Packer, criminal law can be a prime threatener as well as a prime guarantor. It can be a prime guarantor if it is treated humanely and discriminatively. Conversely, it can be a prime threatener, if it is treated coercively and indiscriminatively.

Not suprisingly, both case of Aop Saopuddin and Dharmawati, furthermore attracted a strong reaction from the Indonesian Teachers Association (IGI) who regretted legal proceeding or criminalization against both of the teachers. The argument conveyed by the institution is that the impact experienced by the child is not a serious injury and the actions taken by both are still in the corridor of educating and improving the well-behavior of the wrong students.

Of the cases of Aop Saopuddin and Dharmawati, it appears that the current criminal legislationis not adequate or has failed to become a signboard[21]. The legislation apparently can not provide a clear signal to legal enforcers, relevant parties, and community in order to distinguish which corporal punishment is reasonable and should not be tackled by criminal law, and which one is unreasonable, uncontrolled, and prone to be abuse or physical violence in common, so that it is appropriate to be criminally punished. In this matter, We rely on Coleman's argument, which states that it is important for law to formulate clear distinction between reasonable corporal punishment and unreasonable corporal punishment (tends to be physical abuse). According to Coleman, if the difference between both term is unclear, it will lead to several conditions, such as: (1) the law fails to be a guidance for relevant actors who are enggaged in the settlement of corporal punishment; (2) the bias in figuring out corporal punishment thatwill cause inconsitency of law enforcement; and (3) the risk of errors in identifying so as to cause improperness in applying law and leads to injustice for one of parties[22].

According to Coleman, the issue of corporal punishment is not that simple. All of us should also consider that not all corporal punishment are severe and dangerous. Even if the mild corporal punishment is considered dangerous, the impact on children is not always generalized. Likewise, not all corporal punishment administered to children in similar way will have similar impact on children who grow up in different environment[22]. Each child has a different acceptance of corporal punishment because each of them has different character and conditions. There are some children who consider punishment asa trivial and not harmful act. On the contrary, there are also some children who consider punishment as a serious and detrimental act although it is mild.

In connection with the ambiguity of the interpretation of corporal punishment and abuse, several experts from several related government agencies and criminologists also admitted it. Rini Handayani from the Ministry of Child Protection for example, she states that the current regulations have opened up space for discomfiture and fearness in society, especially those who deal directly with the process ofchild care and education, such as parents, teachers, 
and care takers. In order to avoid such discomfiture, the relevant legislations should substantially provide clear boundaries of the act so that it can be a reference for law enforcement and the community itself[23].

Rita Pranawati as the Deputy of KPAI alsoadmits that the Child Protection Act does not formulate constitutive elements of physical violence, so that the absence of these elements in practice may cause problems in the enforcement of the norms. Therefore, if the law must be revised in the future, it is necessary to also formulate restrictions on the norm, so that law enforcement has a clear reference in qualifying which corporal punishments can be included as physical violence and therefore can be criminally punished. Accordingly, problems of law enforcement such as the case of Aop Saopudin and Dharmawati will not recur[24].

\subsection{A matter of legal defence (Justification)}

Although corporal punishment can be identified with abuse, another problem that must be examined further is related to justification defence of parents or teachers in using this deed against children. However, a criminal act remains a crime, whose justification must, of course, be rational. Moreover, parents are people who deserve respect, given their noble duties and responsibilities in caring for, raising, and educating children.

Indonesian legislation formally does not regulate about juridical reasons tha tmay justify corporal punishment conducted by parents or teachers against children. The mentioned justification defence is only found in the doctrines and decisions of the Hoge Raad in the past, which is called with tuchrecht (some legislations recognize it by term of domestic authority or right to educate).

In some literature, the administration of corporal punishment in the interest of educating and disciplining children is viewed as an unwritten legal defence (justification)[25].The use of that legal defence is justified on the basis of of the abolishment of unlawful acts. According to Clarkson and Keating, parents are justified in using reasonable force against their children, the superior interest is to promote the welfare of the minor and to prevent or punish misconduct[25]. In this case, Clarkson and Keating argue that parents are justified in using reasonable power for the highest interest in realizing prosperity, preventing and punishing children from wrong actions.

Another argument comes from van Bemmelen. He stated that parents, teachers, and people who are responsible for educating children are entitled to seize independence, punish children who are not yet mature under certain conditions. Bemmelen argues that those deeds can not be assumed abuse provided that those deeds are carried out in an educative manner. Regarding this matter, van Bemmelen gave an example of the decision of Hoge RaadNo. W.7723 on February 10, 1902, which stated that "essentially, abuseincluding injuring or hurting a child becomes a goal, and not as a means to achieved suchof a permitted goal, and thus if it is forced by parents or teachers, they may consider hitting a child on a limited basis [26]. However, Bemmelen also firmly affirms that the pattern of educating and nurturing must be within reasonable limits in the logic of society. If the methods of educating and caring are carried out strictly, and using methods that are not fair, then the purpose of educating cannot be used as a justification for parents or teachers' acts[26].

Based on the previous explanation, it can be inferred that Indonesian penal policy has some weaknesses, which can affect the bias in tackling cases of corporal punishment against children. The mentioned weaknesess include, (1) the currentpenal policy governing all forms of abuse or physical violence against children, has not included explicit and specific normative provisions regarding corporal punishment of children. (2) The absence of juridical criteria or limitations on the extent to which the use of violence is permitted as a means of education and care. As commonly known, in the doctrine of criminal law, it is recognized a 
specific justification defence, namelytuchrecht or domestic authority, or right to educate, which is given to parents or teacher in performing their task of educating and nurturing.

Accordingly, the weaknesses above furthermore can affect some negative impacts that are experienced by both the child, parent, teacher or guardian as follows:

1. It potentially leads to overreaction of society. In this matter, public seems to be easy to criminalize or to penalize parents, teachers, and guardians of children for all kinds of punishment which are deemed unpleasant. The absence of an explicit provision prohibiting corporal punishment causes the rule appears to be excessive without sufficient filter to examine the extent to which the actions of parents, teachers, and guardians are seen as a form of pure abuse, and to what extent are seen as corporal punishment.

2. On the contrary, the existence of tuchrecht as a unwritten justification defence may result in neglect of child abuse cases which are veiled in or driven by a good purpose/motivation of educating or disciplining children;

3. The absence of clear criteria or limitations as a guideline to determine the level of fairness of actions in the field of education and care, will result in difficulties or diverse standards used to determine reasonable and unreasonable punishment.

Concerning the description above, it appears that child protection must still be based on the principles of justice. Justice must, of course, be manifested as a constant will to give everyone what they should (iustitia est constants et perpetra voluntas ius sum cuique tribuendi). In this context, the rights of children with the interests of parents, teachers and guardian or caregivers must be placed in balance. The limitations of penal policy nowdays governing corporal punishment against children induce refraction of fulfillment of both interests (children and relevant actors), without the standard of clarity.

\section{Conclusion}

Basing onthe elaboration above, we conclude that, eventhough the current penal policy governing abuse and violence against children can be extended to cope with cases of corporal punishment, nonetheless it is not sufficient to bring justice to all involved parties, most importantly to defendant. The current penal policy has three weaknesses that can affect law enforcement, namely: (1) It potentially leads to overreaction of society. Under the current penal policy, parents, teachers and other care takers will be easily criminalized as well as penalized; (2) the existence of an unwritten justification defence may result in neglect of child abuse cases which are veiled in or driven by a good purpose for children; and (3) The absence of clear criteria will result in a multi-interpretation of legislations amongst legal enforcers. It risks at the application of improper provisions toward corporal punishment.

\section{Recommendation}

We would like to provide two policy recommendations relating to corporal punishment of children, as follows:

1) In order to avoid improperness in applying criminal provisions towards corporal punishment cases, as well as to bring about justice between children and relevant actors (parents, teacher and other care takers), the policy makers should carry out penal reform by formulating a specific provision which criminally prohibit corporal punishment of children.The provision should also provide clear definition of corporal punishment, so that it is clear enough the difference between corporal punishment and physical abuse; and 
2) The penal policy should also include a special justification defence which can be strictly applied to cases of corporal punishment under some certain conditions. The main purpose is to diminish the negative impact of criminal law application toward minor-harmed acts.

\section{References}

1. A. I. Mints, Pain and Education, in a book composed byJennifer Corns, The Routledge Handbook of Philosophy of Pain, Pp. 344(The Routledge Publishing, London, 2017)

2. O. Barnett, Family Violence Across The Lifespan (Second Edition), Pp. 3 (SagePublication, London, 2005)

3. C.H. K. M. D. Denver, F. N. S. M. D. Cincinnati, Brandt F.SteeleM.D, W. Droegemueller, H. K.S. M.D. Denver,Child Abuse and Neglect 9, 2, Pp. 143-154 (1985)

4. Report of the Global Initiative, www.endcorporalpunishment.org (2016)

5. The 27th Universal Periodic Report on Human Rights (Geneva, 2017)

6. E. Suharto, Situasi Anak di Indonesia (Isu-Isu Strategis 2015) (Directorate of Children Social Welfare, 2015) Survey on Violence was composed by Ministry of Social Affairs and Ministry of Women empowerment and Child Protection.

7. E. Prasetyo, HAM Kejahatan Negara dan Imperialisme, Pp. 182 (Insist, Yogyakarta, 2001)

8. H. H. Brownstein, M. A. Zahn, S. L. Jackson,Violence from Theory to Research, Pp. 6-7 (Routledge, London, 2004)

9. Interview with Seto Mulyadi, Head of Indonesian Child Protection Institute, Jakarta, August 24, 2017; Muhammad Mustofa, Criminologist in Faculty of Social Science and Politic -University of Indonesia, Jakarta, August 25, 2017; and Salman Luthan, the Judge of Supreme Court who adjudicated Aop Saopuddin Case, Yogyakarta, October 21, 2017

10. D. Finkelhor., H. Turner, A. Shattuck, S. Hamby, K. Kracke, Children's Exposure to Violence, Crime, and Abuse: An Update, Bulletin Juvenile Justice, Pp.1 (2015)

11. Data of Unicef 2016 based on surveys conducted by DHS, MICS and representative of other countries, 2005-2015.

12. Aliansi Penghapusan Kekerasan terhadap Anak (Aliansi PKTA), Segera Hentikan Praktek Hukuman Fisik (corporal punishment) dalam Dunia Pendidikan Indonesia, www.kampanyepkta.org, (2017)

13. See Judgment released by District Court of Majalengka No. 257/Pid.B/2012/-PN.Mj1, on May 12, (2013)

14. See Judgment released by Appeals Court of Bandung No 226/PID/2013/PT. BDG, on July 31, (2013)

15. Interview with Salman Luthan, The Judge of Supreme Court who adjudicated Aop Saopuddin Case, Yogyakarta, October 21, 2017

16. J. Remmelink, Hukum Pidana, Pp. 9-10 (Gramedia Pustaka Utama Jakarta, 2003)

17. Sudarto, Hukum Pidana I, Pp. 155 (Yayasan Sudarto, Semarang, 1990)

18. D. Benatar, Corporal Punishment, Social Theory and Practice Journal, Vol. 24, No. 2, Summer 1998, p.237-260

19. J. V. Galtung, "classification of violence that has a positive impact" (Reference no. 7)

20. D.Black, "moralistic violence which means the use of violence is a tool to control moral or human behavior" (Reference no. 8)

21. S. Rahardjo, HukumProgresif2, 1 (2006)

22. D. L. Coleman, K. A. Dodge, S. K. Campbell, LCP73, 2, Pp. 107-165 (spring 2010)

23. Interview with Rini Handayani, the Deputy Assistant of Child Protection Affairs in the Ministry of Women Empowerment and child Protection, Bogor, August 24, 2017

24. Interview with Rita Pranawati, Vice Head of Indonesian Commission of Child Protection, Jakarta, August 25, 2017 
25. C.M.V. Clarkson, H.M. Keating, Criminal:Text and Material Pp. 275 (Sweet \& Maxwell Ltd, London, 1994)

26. J. M. Van Bemmelen, Hukum Pidana 1, Pp. 201 (Percetakan Bina Cipta, Bandung, 1987) 